\title{
SELFIE E A TESSITURA DE IMAGENS E CURRÍCULOS INDIVIDUAISCOLETIVOS COM AS REDES EDUCATIVAS
}

- MARIA DA CONCEIÇÃO SILVA SOARES

Universidade do Estado do Rio de Janeiro

VANESSA MAIA BARBOSA DE PAIVA

Universidade Federal de São João del-Rei

JOÃO BARRETO DA FONSECA

Universidade Federal de São João del-Rei

RESUMO Este artigo trabalha com o objetivo de pensar as propriedades de um campo especial de imagens conhecido como selfie, o qual, mais do que um registro fotográfico de si próprio, caracteriza-se pela busca de autoapresentação e conexão com o outro, em redes sociais digitais. Metodologicamente, a partir de pesquisas bibliográficas e iconográficas, analisa as mudanças que sua produção e distribuição provocam na percepção, de modo a produzir um sensorium que é acompanhado de novas configurações, éticas e estéticas, marcadas por uma forte exposição de si, bem como por um afrouxamento de tabus sobre a intimidade, inserindo o corpo no processo de comunicação e, dessa forma, na tessitura das narrativas do presente. As configurações atuais também desarticulam questões referentes à representação que, por muito tempo, dominaram os debates relativos à imagem. Para concluir, sugere que a prática de fazer, divulgar, compartilhar e comentar selfies é complexa e paradoxal, por não ser apenas individual, mas também fruto de modelizações, de memórias, de retóricas e de maneiras de narrar e constituir currículos individuaiscoletivos, em processos de permanente criação de si e de mundos.

Palavras-chave: Selfie. Percepção. Corpo. Conexão. Memória.

\section{ABSTRACT SELFIE AND THE TEXTURE OF IMAGES AND \\ CURRICULUMS INDIVIDUALCOLLECTIVE WITH THE NETWORKS IN AND OUT OF SCHOOLS}

This paper aims to think about the properties of a special image area known as selfie, which, more than a photographic register of your- 
self, it is characterized by the seek for self presentation and connection with others in digital social networks. Methodologically, based on bibliographic and iconographic research, it analyzes the changes that its production and distribution provoke in perception, in a way to produce a sensorium which is followed by new ethical and esthetical settings, characterized by a strong self exhibition, as well as a loosening of tabus about intimacy, inserting the body in the communication process and, with this, in the present narrative's texture. The current settings also disarticulate issues about the representation that, for a long time, dominated the debates about images. To conclude, he suggests that the practice of taking, fostering, sharing and commenting on selfies is complex and paradoxical for not just being individual, but also a result of modeling, memories, rhetorics and ways of narrating and building individualcollective curriculums in processes of permanent self and world creation.

Keywords: Selfie. Perception. Body. Connection. Memory.

\section{RESUMEN SELFIE Y LA TESSITURA DE IMÁGENES Y CURRÍCULOS INDIVIDUALESCOLESCTIVOS COM LAS REDES EDUCATIVAS}

El presente artículo tiene como objetivo pensar las propiedades de un campo especial de imágenes conocido como selfie, el cual, más que un registro fotográfico de sí mismo, se caracteriza por la búsqueda de una autopresentación y conexión con el otro en redes sociales digitales. Metodológicamente, a partir de investigaciones bibliográficas e iconográficas, analiza los cambios que su producción y distribución provocan en la percepción, para así producir un sensorium que es acompañado de nuevas configuraciones éticas y estéticas marcadas por una fuerte exposición de sí mismo, bien como por un debilitamiento de los tabúes sobre la intimidad, insiriendo el cuerpo en el proceso de comunicación y, de esta forma, en la tesitura de las narrativas del presente. Las configuraciones actuales también desarticulan cuestiones referentes a la representación que por mucho tiempo dominaron los debates relativos a la imagen. Para concluir, sugiere que la práctica de hacer, divulgar, compartir y comentar selfies es compleja y paradoxal por no ser solamente individual, sino que también un fruto de modelos, de memorias, de retóricas y de maneras de narrarse y construir currículos individualescolectivos en procesos de permanente creación de sí mismo y de mundos.

Palabras clave: Selfie. Percepción. Cuerpo. Conexión. Memoria. 


\section{Introdução: selfie e o universo fotográfico}

\author{
Cada indivíduo é mais importante \\ que a Via Láctea.
}

Nelson Rodrigues (1992, p. 83)

A ambiência comunicacional, instituída pela presença constante de aparelhos produtores e difusores de conteúdos, pelos regimes semióticos das mídias e pela permanente conexão com outros, por meio de imagens compartilhadas nas redes digitais, caracteriza, cada vez mais, nossa vida cotidiana e engendra narrativas do presente. Vivemos em uma sociedade infotecnológica cercada por dispositivos de imagens que, em dada medida, nos impelem a produzi-las e distribuí-las a todo instante. 0 hábito de fotografar não é novo, mas, em nossa época, a profusão das fotografias produzidas e distribuídas cotidianamente por não profissionais e a compulsão por fotografar tudo e todo o tempo talvez devam ser pensadas nessas contingências.

A fotografia, como define Flusser (2002), é uma imagem técnica produzida por um aparelho-operador, cuja principal característica é ter sido programado pelo fabricante para nos induzir a fotografar. Se considerarmos o aparelho-operador por esse prisma, o que o caracteriza é o fato de estar programado. Dessa maneira, as imagens que ele produz estão previamente programadas por aqueles que 0 fabricaram. As fotografias seriam, então, realizações de algumas das potencialidades inscritas no aparelho. O fotógrafo agiria em função da realização do universo fotográfico. Flusser (2002) propõe que a análise do gesto de fotografar pode se constituir em um exercício para a análise da existência humana na sociedade pós-industrial, aparelhada, na qual tudo que é fotografável deve sê-lo.

Sontag (2004, p. 17), considerando que a industrialização da tecnologia da câmera de fotografar instituiu uma "[...] mentalidade que encara o mundo como uma coleção de fotos potenciais", analisa o ato de fotografar como um modo de apropriação do mundo semeIhante ao conhecimento e ao poder. Para ela, “[...] fotografar é apropriar-se da coisa fotografada" (2004, p. 14). Dessa forma, a prática de fotografar é um rito social, uma proteção contra a ansiedade, uma atitude de pertencimento e um instrumento de poder.

A imagem fotográfica, segundo Martins (2008), criou uma visualidade própria da sociedade industrial. Sem a fotografia, afirma, a cotidianidade seria impossivel. "De certo modo, em boa parte, hoje, pensamos fotograficamente" (MARTINS, 2008, p. 43). E acrescentamos: de algum modo, nos percebemos e produzimos nossa autoimagem fotograficamente.

Isso não significa que podemos reconstituir a realidade do mundo com as fotografias que se propõem a retratá-lo, pois, conforme advertiu Canclini (1987), toda fotografia carece de objetividade, embora possa ser analisada como um modo de referir-se ao real. Para esse autor, apesar da ambiguidade que the é inerente, a imagem fotográfica pode cumprir um papel cognoscitivo, ao propor olhares não familiares sobre o mundo. Nesse sentido, conhecer significa "[...] abrir o presente ao pressentido" (CANCLINI, 1987, p. 16).

Dada a ambiguidade atribuída ao registro fotográfico, a imaginação torna-se um aspecto inerente tanto às práticas de produzir como às de pensar com imagens técnicas. Para Martins (2008, p. 28):
[...] a fotografia é muito mais indício do irreal do que do real, muito mais o supostamente real recoberto e decodificado pelo fantasioso, pelos produtos do auto-engano necessário e próprio da reprodução das relações sociais e do seu res- pectivo imaginário. A fotografia, no que supos- tamente revela e no seu caráter indicial, revela também o ausente, dá-lhe visibilidade, propõe- se antes de tudo como realismo da incerteza. 
Considerar que as fotografias se constituem como documentos ambíguos, implica pensar que elas remetem, simultaneamente, a realidades e ficções, experiências e prospecções, revelações e ocultações, que, como adverte Kossoy (2007), não devem ser tomadas dogmaticamente como uma verdade histórica.

Muito mais do que verdades, as fotografias produzem presenças (GUMBRECHT, 2010); trazem para diante de nós pessoas, coisas, lugares, temporalidades e acontecimentos. Apesar da centralidade do olhar no processo de ver, dar a ver e ser visto, as presenças fabricadas com as imagens afetam nossos corpos e nossas sensibilidades, produzem tilts em todo o nosso ser, como disse Barthes (1984). Tais presenças, criadas com as imagens e com o que elas nos permitem testemunhar, nos convocam a experimentar uma atitude possivel diante do que nos é apresentado e, dessa forma, impulsionam aprendizagens culturais e alargam nossas redes de saberesfazeres.

Gumbrecht (2010), em busca de novas epistemologias para abordar o que há no espaço da experiência não conceitual, defende que a produção da presença potencializa experiências estéticas que podem dispensar o que seria uma redução hermenêutica da significação, suscitando epifania, ou seja, uma apreensão súbita de algo a partir da presentificação produzida com as imagens.

Nas culturas visuais em que estamos imersos, as fotografias tornam as coisas visiveis e presentes para nós, inteligiveis ou não para nós, criando aparições que nos levam a experimentar o mundo como imagem e nos oferecem modelos a serem imitados nos processos miméticos que caracterizam parte significativa das aprendizagens culturais. Os processos miméticos, para Wulf(2013), são formas produtivas de imitação que produzem sempre diferença em relação ao modelo original. As fotografias, entre outras narrativas, fornecem repertórios para o imaginário individual e coletivo no qual se forjam os modelos a serem imitados. Segundo esse autor, "[...] com a ajuda da imaginação também são incorporadas em processos miméticos as imagens de outras pessoas, outros mundos e outras vidas. A educação pode ser compreendida como um processo mimético no qual a crítica ao modelo também desempenha um papel importante" (WULF, 2013, p. 14).

As imagens fotográficas, nessa contingência, indicam comportamentos convenientes e condenáveis, interrompem fluxos cognitivos habituais, produzem estranhamentos, concentram gestos emotivos que remontam a experiências milenares e apresentam modos de ser e fazer a serem imitados, recusados ou transformados. Esses modos nos servem de referência e repertório para o imaginário que informa a autocriação em busca da aceitação, do reconhecimento, do pertencimento e dos benefícios sociais, econômicos e políticos que deles decorrem.

Atualmente, para além do barateamento e da diversificação dos aparelhos que produzem imagens, ficou fácil e rápido fazê-las circular. Os aparelhos, constantemente desenvolvidos/ modificados/afinados aos modos de consumo e aos usos, vão incorporando possibilidades engendradas com as práticas de produzir e divulgar imagens nas redes digitais, com destaque especial para os smartfones, que possibilitam, além da operacionalidade, a mobilidade na produção, recepção, compartilhamento e edição de fotografias.

Vale ainda ressaltar que, conforme destacou Miskolci (2012), o uso contemporâneo das mídias digitais implica mais uma etapa na dessacralização das relações pessoais, isto é, o embaralhamento das fronteiras entre o privado e o público, que teria começado com a popularização do uso do telefone e se intensificado por meio da articulação do telefone e do computador pessoal, o que tornou possí- 
vel a expansão da internet. Atualmente, acessamos a internet pelos celulares. Na verdade, estamos/ficamos nela quase todo o tempo, em quase todos os lugares, o que significa mobilidade e ubiquidade no acesso às redes digitais.

Os modos contemporâneos de praticar fotografias situam-se, dessa forma, em meio ao que Jenkins (2009) chama de cultura da convergência, conceito que se relaciona não só com o desenvolvimento das tecnologias da informação e da comunicação, como também com os usos de seus processos e produtos pelos praticantes da cultura, os quais, a partir desses usos, se tornam produtores (CERTEAU, 1994). De acordo com Jenkins (2009), convergência é a palavra que consegue definir as transformações tecnológicas, mercadológicas, culturais e sociais que estamos experimentando. Nessa perspectiva, a convergência, compreendida como a circulação de conteúdos através de múltiplos dispositivos de mídia, depende da participação ativa dos usuários, não apenas como consumidores, mas, principalmente, como produtores e distribuidores de conteúdos.

A presença, em toda parte, de dispositivos produtores e distribuidores de imagens possibilita àqueles que as praticam dramatizar a vida cotidiana, tensionar o previsível, ficcionar sobre si e sobre sua relação com o mundo, imaginando, fabulando e experimentando performaticamente novas possibilidades de criar ética, estética e politicamente, suas existências. As narrativas imagéticas exibidas cotidianamente nas diferentes telas compõem as escritas superficiais, híbridas, efêmeras e sensiveis do mundo e de cada pessoa ou grupo social, com os quais experimentamos, compomos e compartilhamos o presente.

Uma selfie, como a imagem resultante da prática de se autofotografar, não é, contudo, somente um registro fotográfico, pois faz parte de um discurso-fluxo, que, precedendo seu autor, pertence a um campo de expressão am- bíguo, o qual, mesmo se constituindo em uma prática singular, não é posse ou elaboração exclusiva de alguém. Fazer selfie, atualmente, também é uma possibilidade inscrita no principal aparelho usado com essa finalidade, o smartfone, que, incorporando práticas bem antigas combinadas com os usos que dele começou a se fazer há alguns anos, agora já vem equipado também com câmera frontal, além da câmera fotográfica comum. Além disso, é possível, nos dispositivos de produção de imagens digitais, ver a fotografia no próprio aparelho, deletá-la ${ }^{1}$ e fazer outras quantas vezes for necessário até que a imagem, sem ou com edição feita no próprio aparelho, agrade ao autor que é, ao mesmo tempo, o retratado.

Foto 1 - Selfie praticada antes da câmera frontal em dispositivos móveis de imagens: táticas de usuários. ${ }^{2}$

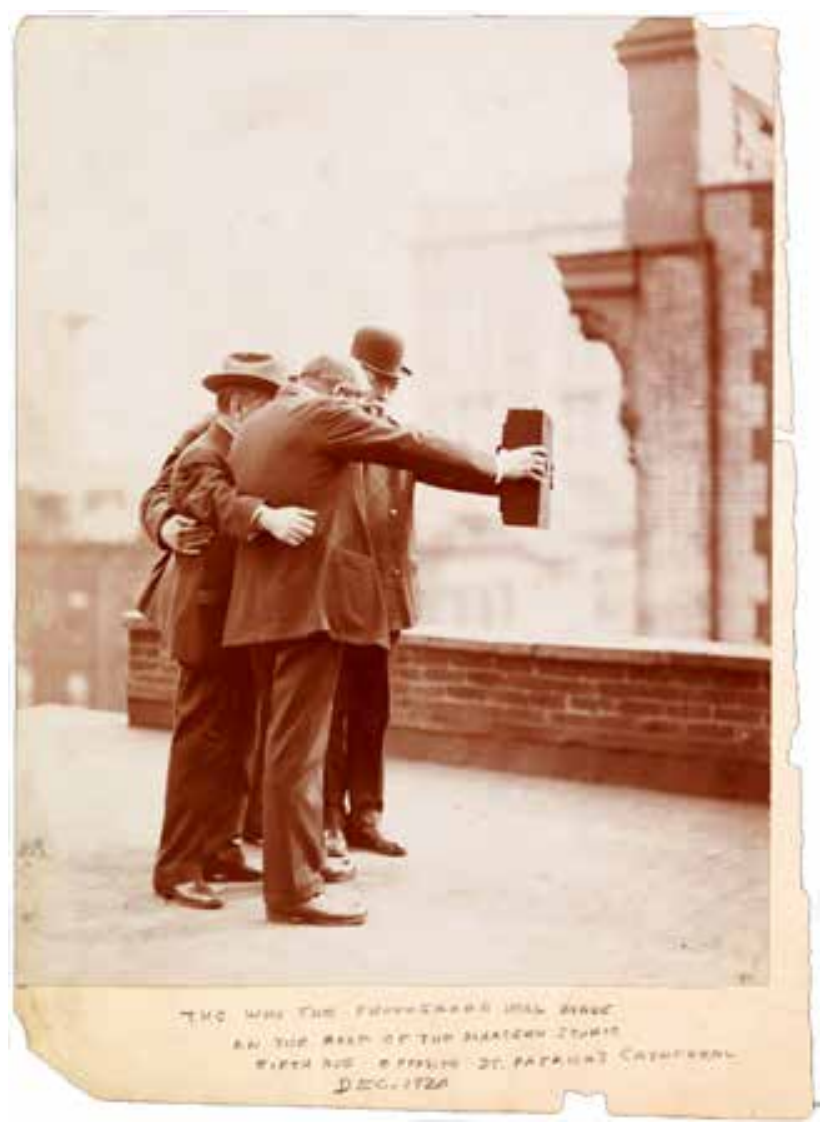

1 Deletar quer dizer apagar um arquivo, imagético ou não, no dispositivo digital.

2 Disponivel em: <http://www.elperiodico.com/es/noticias/sociedad/primera-selfie-historia-1920-3159109>. Acesso em: 15 mai. 2017. 
Em uma ambiência em que é preciso ver, mostrar e fazer ver para existir, novas relações de poder, saber e prazer engendram efeitos de realidade e regimes de verdade atrelados às imagens (BRUNO, 2010). As subjetividades, da mesma forma, encontram-se, cada vez mais, investidas nos processos do ver e do ser visto.

Analisar a prática de fazer selfie com o smartfone, apropriando-nos do pensamento de Flusser (2002), pode se constituir em um exercício para analisar a existência humana neste século XXI. Fazer uma selfie com smartfone conectado à internet implica produzir e compartilhar a imagem que se deseja de si próprio, sozinho ou em grupos, nas redes sociais. Acompanhando esse modo de constituir a autoimagem, diferentes programas de edição de fotografias podem ser baixados nos aparelhos para serem usados na criação da imagem que vai ser compartilhada.

Segundo Eva Illouz, citada por Miscolci (2012, p. 7), a selfie “[...] se transforma em uma espécie de mercadoria na vitrine, em competição com outras, o que explica como a cultura do consumo influencia e até mesmo define a forma como as pessoas tentam, por meio de textos e imagens, criar uma impressão que agrade e seduza [...]". Para o autor, isso leva a um processo de conscientização da centralidade do corpo em um mercado performativo de imagens altamente competitivo.

A prática de fotografar a si próprio e, dessa forma, produzir-se em/como imagem, constitui-se de intenções e escolhas e, de modo evidente, por uma tentativa de autoapresentação, autorrepresentação e conexão com o outro em redes sociais, visando a provocar um determinado tipo de visibilidade, que é também uma alteridade de si mesmo, mudando o estatuto do corpo em decorrência de seus desdobramentos virtuais, que se atualizam diferentemente no universo de leituras da coexistência digital.

\section{Selfie e os currículos fabulados}

\section{nas/com as redes educativas}

Qualquer maneira de imaginar é uma maneira
de fazer política.

Didi-Huberman (2011, p. 60-61)

No pensamento de Bergson (1990), encontra-se a premissa de que os seres vivos refletem a luz dos objetos impedindo a imagem de prosseguir seu caminho rumo ao infinito. Segundo o filósofo, os seres vivos seriam, assim, um centro de indeterminação, pois a imagem estaria presente a partir de um campo de percepção, que nos permite extrair dos objetos aquilo que nos interessa.

Pascal Bonitzer, citado por Rezende (2013, p. 49), apresenta outra questão derivada da recepção das imagens: “[...] sobra para o espectador se virar com as liberdades que o simulacro toma, quando este deixa de se comportar como um reflexo obediente". Com esse argumento, como ficaria o processo de captação, pós-produção, circulação e fruição da selfie? 0 conceito de representação não dá mais conta desse debate, uma vez que a selfie, embora encontre seu lastro no real, não se apresenta como reprodução. Não temos aí uma sugestão convencionada de um objeto a ser reproduzido nem mais a intenção de fabricar uma semeIhança e muito menos importam as insuficiências de semelhança em relação ao que está sendo fotografado.

Seguimos, então, as pistas deixadas por Gonçalves e Head (2009, p. 7), que entendem “[...] as imagens como propulsoras de novas perspectivas sobre temas clássicos como representação, alteridade, subjetividade, individualidade e imaginação". Com a noção de devir-imagético, esses autores apontam um dos modos pelos quais outras estéticas de existência emergem com os processos de produção imagética: 
O devir-imagético - enquanto uma noção mais abrangente - aponta para a imaginação/criatividade pessoal e para a 'pessoalização' dos processos culturais que é capaz de efetuar. Neste sentido, a criação do devir-imagético via fabulação é justamente 'monstruosa' no sentido que ganha vida própria através da conjunção de fatores pessoais e impessoais tais quais as tecnologias, as instituições, os acontecimentos e produtos do 'acaso'. (GONÇALVES; HEAD, 2009, p. 29)

De fato, o conceito devir-imagético busca mostrar a possibilidade de emergência de personagens que se apresentam e se representam a partir de uma relação em que as imagens são pensadas como formas de extensão de um suposto "eu" em direção a um suposto "outro", implicando a intersubjetividade, a multiplicidade, a performatividade e a encenação em meio às quais nos constituímos. Nesse processo, o que está em jogo é a ampliação da capacidade imaginativa, o que possibilita outros modos pelos quais os indivíduos imaginam a si mesmos e os outros, instituindo uma função fabuladora por meio da qual se cria o que pretensamente se retrata.

$\mathrm{Na}$ fotografia, muito se disse que a escolha de ângulos, enquadramentos etc., coloca o sujeito-fotógrafo na fabricação do objeto. No caso da selfie, além de suas intenções, o fotógrafo, que é, simultaneamente, o fotografado, insere o corpo na fotografia. Se as poses e os estados de ânimo provocam uma alteridade, uma virtualização em relação ao objeto fotografado, estamos, cada vez mais, distantes de uma possibilidade de representação do real tal qual espelho. Todas essas virtualizações contidas numa selfie são como nuvens que acompanham a "objetividade" fotográfica do mecanismo de produção da selfie. Não existe uma realidade a ser remontada, pois a selfie tem intenção de promover uma criação, e não reproduzir um dado mundo histórico e geográfico preexistente.
Na selfie, poderíamos pensar a imagem que difere de si mesma: a foto que é uma alternativa ao momento do registro, que é uma composição que não existe mais, mas que nunca se pretendeu como registro do que já foi, como é o caso da fotografia clássica. É um registro, portanto, de uma passagem, de uma duração, de uma memória, de uma virtualidade. Então, imitação e invenção, dois “[...] produtos complementares da atividade humana", como requer Pierre Francastel (1993, p. 31).

Para Nízia Villaça (2007, p. 54), o corpo contemporâneo, em composição com as tecnologias digitais, estabelece um paradigma estético, produzindo devires singulares e inesperados, "[...] surgindo como carne e imagem, matéria e espírito simultaneamente". Como experiência estética, na concepção de César Guimarães (2006, p. 16), podemos pensar a selfie como "[...] alargamento e enriquecimento daquilo que até então constituía o limite de todo real possivel". Para o autor, as práticas performativas introduzem de maneira provocativa um ponto de vista desviante. O corpo coloca-se na busca de algo que se considere merecedor de compartilhamento, com o intuito de produzir um instante, algo que arranhe o regime de atenção corrente, nem que seja por um momento fugaz.

Dessa forma, movimentamos nosso pensamento para a perspectiva da selfie como uma possibilidade de engendrar a tessitura de currículos individuaiscoletivos em/com imagens singulares e, ao mesmo tempo, informadas por repertórios hegemônicos, nas/com as redes educativas. Trata-se de uma fabulação imagética de identidades, histórias e memórias sobre si mesmo, sobre o grupo social ao qual se pertence ou se quer pertencer, sobre a vida que se quer ter e mostrar, inclusive sobre a vida nas escolas.

Alves (2001) pensa os espaçostempos escolares e tudo que neles acontece como dimen- 
sões materiais dos currículos tecidos em redes, indicando a necessidade de assumirmos a multiplicidade e a complexidade dos processos curriculares. Nessa perspectiva, a autora sugere "[...] a necessidade de usar a imagem, como espaçotempo, para a discussão sobre o cotidiano da escola e os múltiplos currículos que aí são criados e estão em permanente disputa" (ALVES, 2001, p. 56). A partir de Certeau (1994), Alves (2010) indica que os praticantes das escolas vão organizando as táticas com o que fazem dos diversos artefatos, de ideológicos a tecnológicos, que lhes são impostos pelas políticas curriculares e pelo mercado e, com esses usos, vão intervindo nos processos curriculares e pedagógicos, fazendo com que mudanças aconteçam em relação ao que foi prescrito, planejado e pensado oficialmente.
Assim, ao modo das táticas (CERTEAU, 1994) - uma modalidade de prática em que os usos de artefatos culturais engendram uma produção secundária implicada a outros interesses e outros desejos para além do que é imposto pela indústria, pela grande política e pelo mercado -, a prática de fazer selfie pode se tornar um potente mecanismo para a autoapresentação e a autorrepresentação. Atitude capaz de subverter a lógica normalizadora e disciplinarizadora, predominante em imagens tradicionais e/ou oficiais de escolas que apresentam alunos enfileirados, organizados por gênero ou tamanho, em degraus, uniformizados, limpos, penteados, tornando quase impossivel reconhecê-los, tamanha a homogeneização das imagens de seus corpos (Foto 2).

Foto 2 - Fotografia tradicional de escola: uniformização e organização dos corpos.

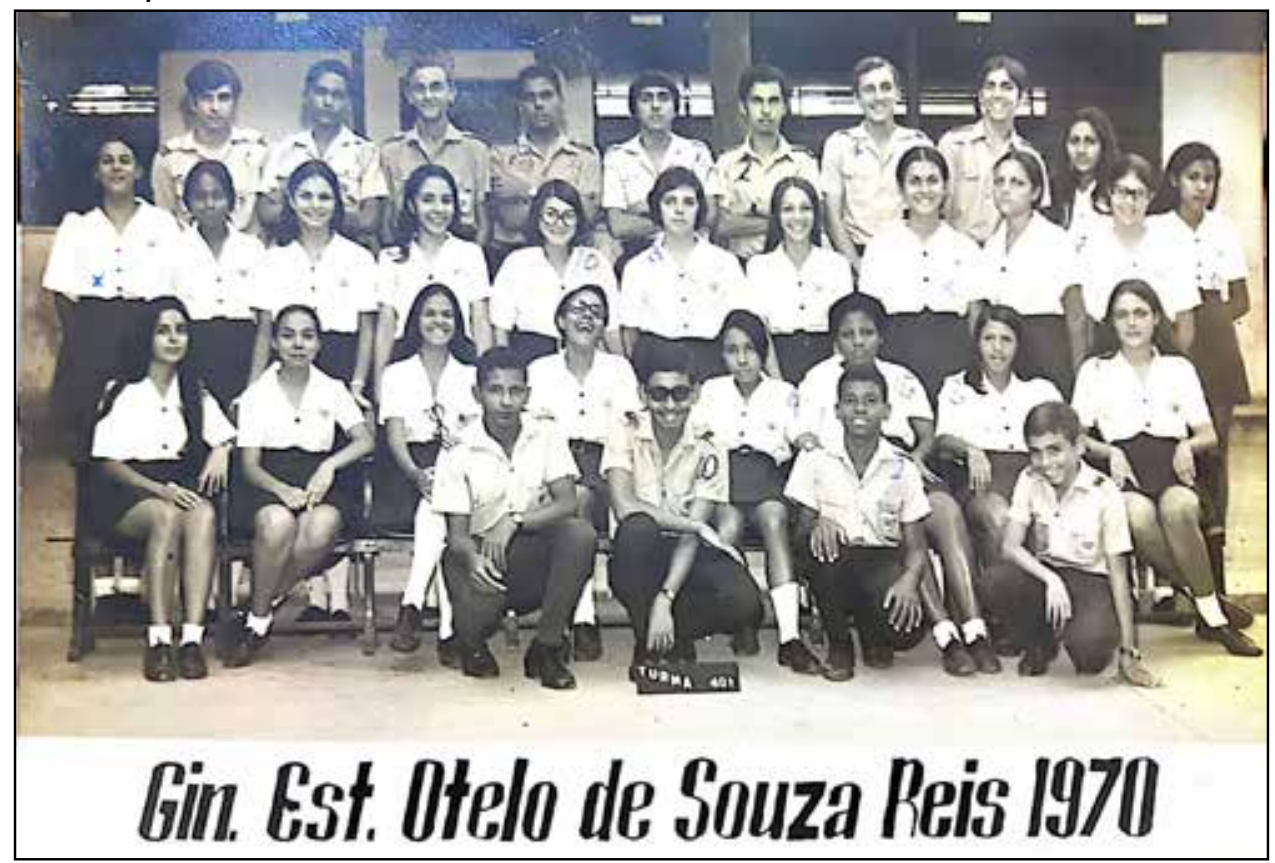

Fonte: Acervo pessoal de um dos autores.

Isso para não nos remetermos a modelos antigos, mas ainda seguidos por fotógrafos profissionais, que retratam estudantes posando sozinhos, com mapas, bandeiras ou painéis com o nome da escola atrás, capelo na cabeça, lápis, globos, livros e/ou objetos sobre a mesa, compondo um cenário que indica, preferencialmente, que escola é lugar, apenas e/ou principalmente, para estudar e aprender com artefatos fabricados unicamente com essa finalidade ou indicativos de modernização. 
Foto 3 - Na foto produzida por profissional, uma composição com personagens da Disney, telefone e cabelo penteado à moda da época.

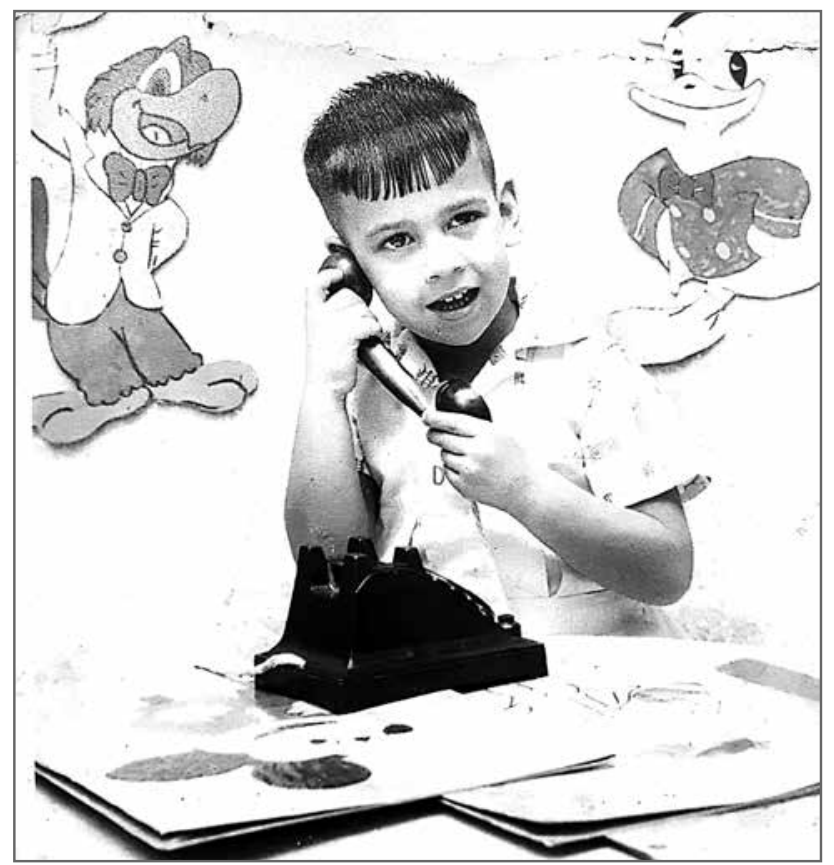

Fonte: Acervo pessoal de um dos autores.

Foto 4 - Capelo e diploma, como manda o figurino.

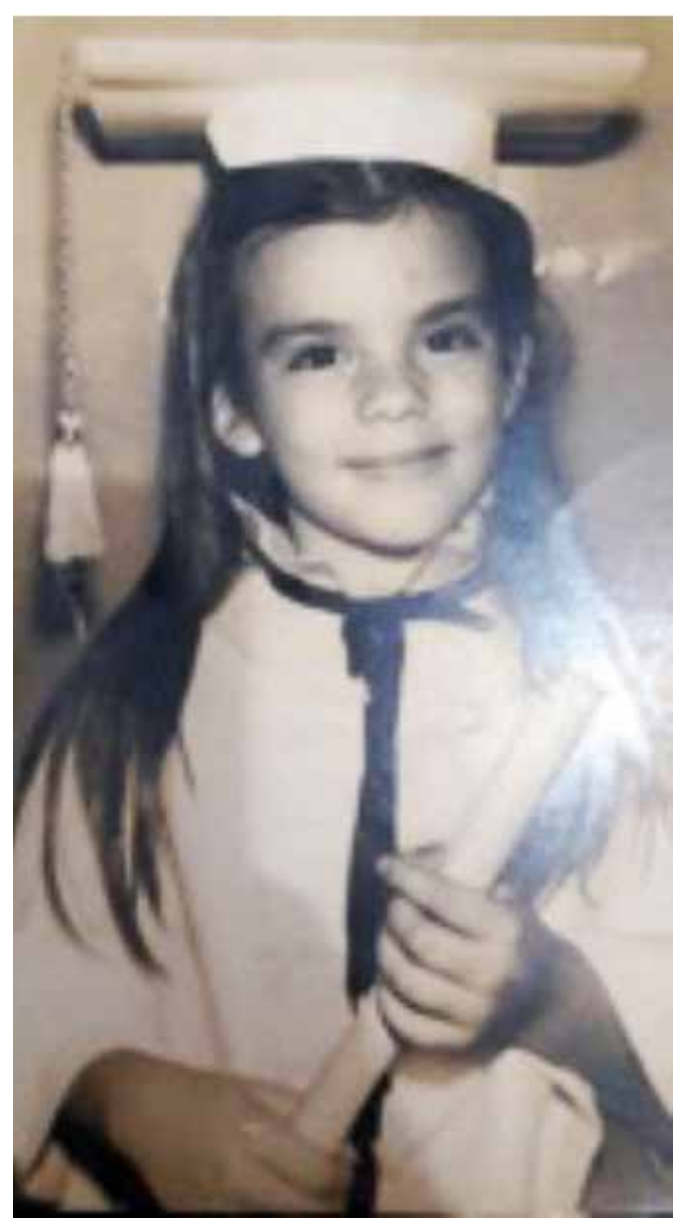

Fonte: Acervo pessoal de Virgínia Louzada.
Muitas outras fotografias, feitas por fotógrafos profissionais, diretores, coordenadores, pedagogos, professores, mães, pais e estudantes, constituem crônicas visuais das escolas, produzindo memórias e histórias, especialmente nos dias de festas, competições esportivas, paradas cívicas, feiras de ciência, visitas a museus, passeios, entre outros momentos e dias especiais. São memórias e histórias de escolas e de espaçostempos curriculares produzidas e compartilhadas por meio de fotografias tradicionais e/ou tecnologias digitais, que criam identidades e comunidades, organizadas a partir de calendários escolares e projetos pedagógicos.

Isso, porém, não significa que os currículos produzidos com as práticas cotidianas nas escolas se reduzam à disciplinarização e à docilização dos corpos, à transmissão e aquisição de conhecimentos unicamente escolares e à normalização dos comportamentos e subjetividades. Contudo, as narrativas imagéticas assim produzidas operam como estratégias que buscam contabilizar e expressar os cotidianos escolares como se assim o fossem. Mesmo nesses casos, quando observamos tais imagens com um olhar afinado para o que escapa, o que difere, o que não se deixa aprisionar, o que se cria com os usos que se faz do que é imposto, encontramos, vez por outra, situações, movimentos corporais, olhares, sorrisos, gestos e outros indícios de pequenas transgressões que desestabilizam as pretensões de controle e ordenamento.

Por outro lado, quando estudantes produzem selfies com suas turmas ao fundo ou em meio às atividades escolares exercidas, eles se colocam na cena, ou em cena, como protagonistas das narrativas e das fabulações que produzem, muitas vezes furtivamente, com/ em imagens que remetem a modos outros de habitar o espaçotempo escolar, de forma particular, afetiva e autorrepresentativa. 
Assim, na produção mais diversa de selfies de rosto colado com colegas de sala/escola e/ ou com os professores que admiram, fazendo piadas, caretas ou gestos irônicos, os estudantes vão deixando de lado as "verdades" produzidas sobre eles e usam a selfie com uma função fabuladora em oposição às "verdades" constituídas. Com isso inauguram uma capacidade de criar "uma memória", "uma lenda", uma "autorrepresentação" “A auto-representação estaria aderida a uma função do devir da personagem real e de seus mundos quando ela própria se põe a ficcionar" (GONÇALVES; HEAD, 2009, p. 21).

Foto 5 - Caras e bocas na/com a produção da autoimagem pelas estudantes.

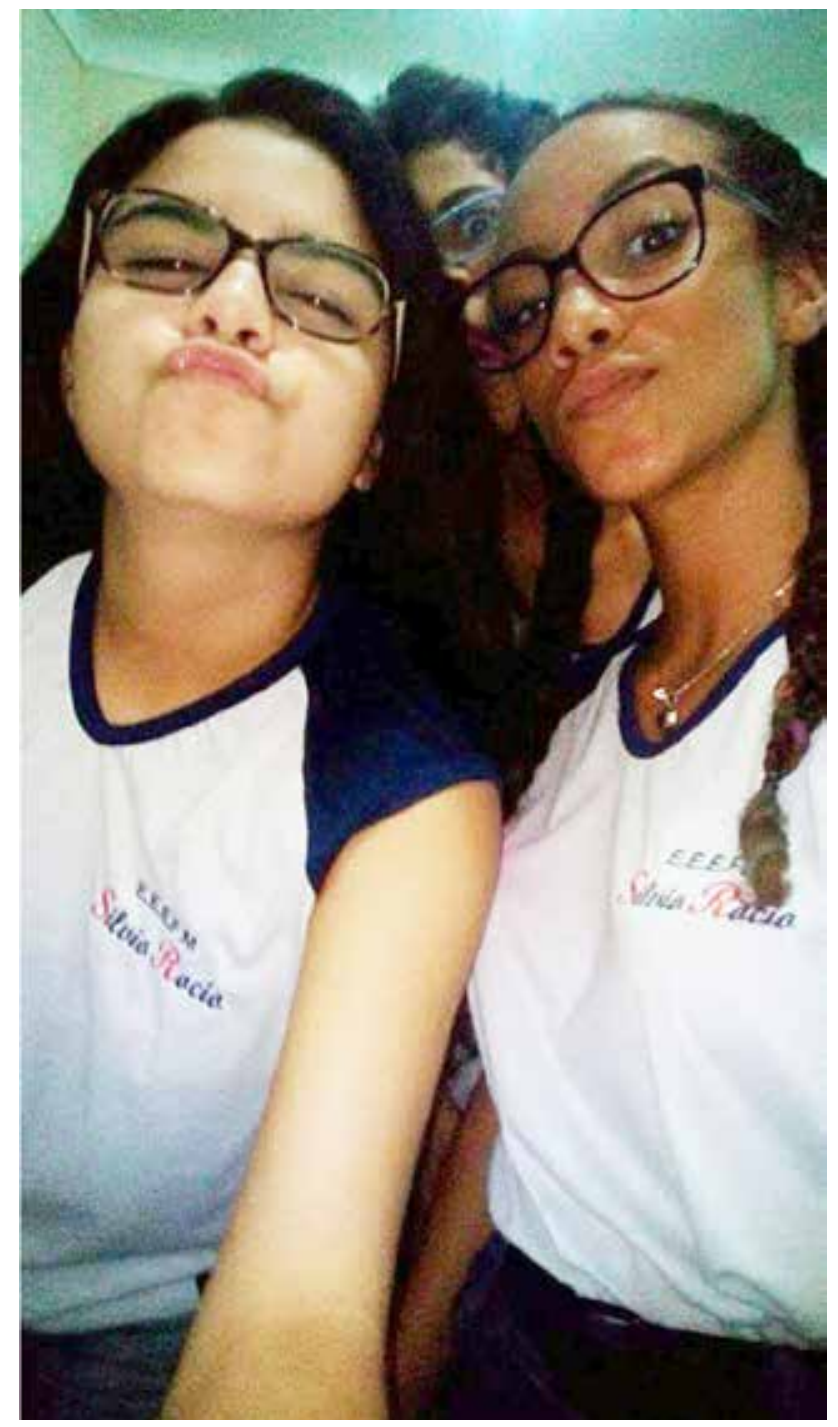

Fonte: Acervo da professora Tatiana Goldring.
Foto 6 - Devires imagéticos que fabulam novas relações entre discentes e docentes dentrofora da escola.

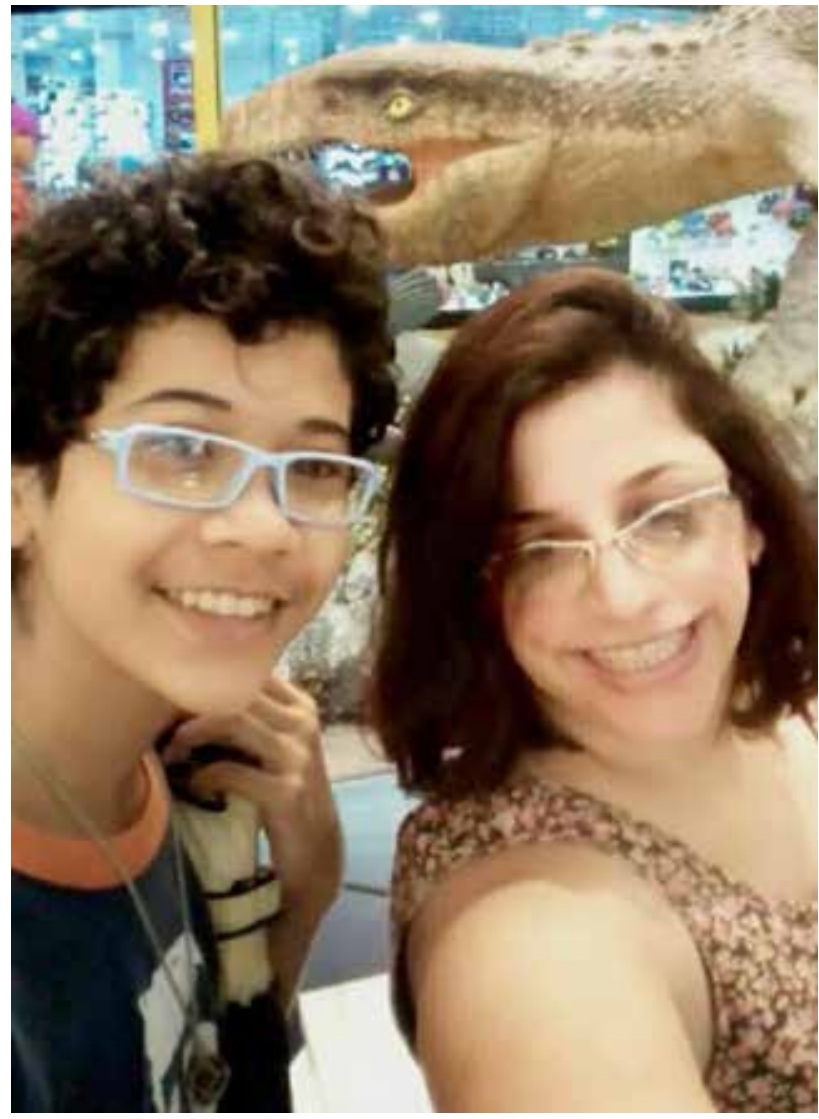

Fonte: Acervo da professora Tatiana Goldring.

Com a contribuição de Gonçalves e Head (2009), em relação à função fabuladora das imagens e ao devir da autoimagem, entendemos que as selfies dos estudantes provocam uma proliferação de autorrepresentações nas quais seus protagonistas se apresentam diretamente formulando seu próprio ponto de vista e sua percepção sobre o modo como desejam ser representados e apresentados, sobretudo nas escolas. Tais imagens fabulam outras possibilidades para os currículos e as práticas, nas escolas, ao instituírem outras memórias individuaiscoletivas.

Selfies publicadas nas redes sociais e legendadas com hashtag" "Rolezinho no pá-

3 Hashtag (nas mídias sociais de sites e aplicativos) uma palavra ou frase após uma cerquilha (\#) usada para identificar mensagens relacionadas com um tópico específico, conforme Dicionário de Língua Inglesa Oxford (2014). 
tio com os amigos"; "Melhor turma"; "Aquela aula que você respeita"; "Durante a aula eu faço selfie" ou o nome da disciplina seguida da selfie ou de expressões como "A hora mais legal"; "Fazer arte é criar" ou "O melhor time no melhor jogo" também são pistas potentes para pensarmos os currículos instituídos e os currículos que os praticantes das escola desejam, produzem, praticam. Da mesma maneira, quando os professores produzem selfies com seus alunos, anexando suas hashtags, vivenciam essa partilha do sensivel no/com o mundo escolar, compartilham do pertencimento a esse ambiente, produzindo atos estéticos como configurações da experiência. Ensejam, assim, novos modos do sentir e induzem novas formas de subjetividade política "[...] um regime específico de identificação e pensamento, [...] um modo de articulação entre maneiras de fazer, formas de sensibilidade" (RANCIĖRE, 2009, p. 11-13).

Compartilhar o universo das escolas a partir das selfies evidencia sensibilidades que instituem a existência de um comum partilhado. O que está em partilha é o que está sendo habitado e não apenas frequentado. A partilha, segundo Rancière (2009), é, ao mesmo tempo, dos lugares, dos tempos e dos tipos de atividades. Diz respeito à maneira como “[...] um comum se presta à participação e como uns e outros tomam parte nessa partilha" (RANCIÈRE, 2009, p. 15). A selfie, como parte de um currículo tecido em redes educativas, é um instantâneo, um recorte, um click de temposespaços do que se dá a ver e do que se oculta, do que é dito e do que é calado. Tudo isso define, ao mesmo tempo, o lugar e o que está sendo disputado nas redes de significações nas quais se quer tecer, habitar e praticar. A selfie entra no estatuto das formas de visibilidade, do que se quer que seja visto e de como se quer ser visto.

Os estudos da atenção dão conta de que o extremo é sempre mais evidente. A aborda- gem, em ângulos diversos, de antigos temas proscritos do contrato social, comprova uma fragilização, que impulsiona para novas experimentações no campo ético e estético.

Duchamp (apud MINK, 2000) havia questionado o destino da arte a partir dos objetos que a indústria produz, daí transferiu a ênfase do objeto para o conceito. As condições contemporâneas não estariam fazendo o mesmo com as imagens que são socializadas diuturnamente nas redes? Não são postadas diariamente fotos que apresentam novos modos de realização e de ver, porém sem a solenidade e a crítica que tornam essas imagens relevantes? Não é qualquer imagem que gera ruptura. Os movimentos para a conquista do merecimento de uma exposição compartilhada são diversos e surpreendentes. Como um espelho que produz imagens que são alterações, como no filme Eu quero ser John Malkovich, a imagem especular é uma variante. ${ }^{4}$ Mas, no caso das práticas da selfie, as imagens correspondem a procedimentos que abrigam, num mesmo processo, a identidade e a alteridade de maneira não dicotômica. Trata-se da produção de "diferença em si" que, como explica Deleuze (1988), comporta um processo de singularização não dialético, de diferenciação permanente, de criação e afirmação de uma estética da existência.

\section{"Só mais uma" ou caminhando}

\section{para uma conclusão}

Por esse viés, podemos então dizer que produzir selfie incorpora elementos bem heterogêneos como um corpo biológico com localização histórica e geográfica; uma prática de compartilhamento em rede, que também representa um momento social; e a habitação e a partilha de um espaçotempo marcado por

4 Disponivel em: <http://image.tmdb.org/t/p/original/ s94S8EBZ09wHJUc4neKxPxR9W6T.jpg>. Acesso em: 16 jun. 2017. 
uma presença fotográfica autorrepresentável. Há heterogênese também na distribuição e recepção dessas imagens, a notar pelas características visuais específicas que as enquadram em um conjunto de imagens e pelas intenções para as quais elas são compartilhadas (despertar ternura, admiração, inveja, provocação, ironia, pertencimento, protesto etc.), dentro de uma lógica distributiva de afetos. Embora seja relativamente nova, a selfie já conta com certas características que a posicionam num ambiente estético, cujo horizonte é regulado por produtores e consumidores.

Mesmo com sua natureza descartável, já possui um "corpus", um repertório de referências que, apesar da larga margem de inventividade, se apresenta com suas estruturas particulares, técnicas, seus recursos, semelhantes ao que poderíamos chamar de "princípio organizativo", para lembrar Bill Nichols (1997, p. 53). Contudo, a "voz da selfie" é paradoxal, por não ser apenas individual, mas também fruto de herança (embora nova), de modelizações (embora não muito rígidas), de memórias (de selfies de outros e próprias), retóricas e maneiras de se narrar.

o celular herdou do vídeo a capacidade de se desdobrar em gravação e transmissão, por ter duas máquinas com junções distintas (a câmera e o monitor), o que o capacita a dar uma resposta imediata, ou seja, um feedback instantâneo. Daí a comparação da selfie com o espelho ser tão apropriada. Basta um clique para uma aparição. Essa simultaneidade fez a fotografia de si se distinguir de outras artes, como a pintura (pigmentos na tela), a escultura (matéria no espaço) e o cinema (luz na película).

Embora a estética seja uma questão, o assunto não deve ser levado ao seu sentido tradicionalmente aplicado na arte, mas deve servir para balizar novas experiências, mais relacionadas com a reinvenção de si e de mundo e, assim, de escolas e de processos curriculares. Por reinventar condições novas, a selfie também não poderia ser chamada de autorretrato, o qual era feito com a intenção de durar e, portanto, em um campo de intenções que reivindicam o status de arte, como podemos notar nos trabalhos de Salvador Dali, ${ }^{5}$ Rembrandt ${ }^{6}$ e muitos outros.

A selfie insere-se como uma possibilidade tecnológica de autorrepresentação e de autoapresentação, que engendra movimentos contrários às representações dos outros sobre nós. Selfies produzem imagens felizes do universo escolar, de brincadeiras, de amizades, de experiências dentrofora das escolas. Abrem também para a intrusão de um devir outro, de bem-estar, beleza ou de alegria, porque, quando não gostamos de uma selfie, temos a possibilidade de deletar a imagem e criar outra que nos agrade. $O$ ato de deletar e criar outra imagem, inclusive modificando-a com os recursos disponíveis no aparelho, não configura uma falsidade sobre si ou sobre o mundo, mas uma fabulação sobre como queremos nos ver/ mostrar e ver/mostrar a escola em que estudamos/trabalhamos, os lugares que habitamos, os locais em que estamos. Mostramos com novas selfies a nossa capacidade de fabulação e de imaginação.

Esse corpo e esse mundo que aparecem na selfie são menos realidade representada (no sentido de montar a realidade como um quebra-cabeça, cujo sentido já é previamente dado) do que uma prática transformadora; mais um processo do que um produto, embora sua face artística possa despontar, pois, como agente de subjetivação, em vez de mero alvo de construção, pode criar sentidos desviantes

5 Disponivel em: <http://2.bp.blogspot.com/-8xrehtja30s/TaLrWOE5z4I/AAAAAAAAAFc/qaWUKECpybo/ s1600/dali.jpg>. Acesso em: 16 jun. 2017.

6 Disponivel em: <http://images.vozpopuli. com/2016/08/05/next/Autorretrato-Rembrandt_941615925_2459638_1020x574.jpg>. Acesso em: 16 jun. 2017. 
não previamente descritos. A reinvenção de si e do mundo tem muitas facetas. Reinventarse é uma característica afirmativa, diria Jean Rouch, que fez, com Edgar Morin, Crônica de verão, documentário clássico do cinema-verdade francês, em que sua presença marca sua adesão àquele tipo de cinema. Sem a presença do cineasta, não seria cinema-verdade. Uma espécie de selfie em movimento. Hitchcock, Tarantino e muitos tantos, ao seu modo, são exemplos de artistas que geram a própria figura dentro de suas obras. Assim como nos filmes desses diretores, a união entre criador e criatura traz à selfie antigas questões sobre autoria do processo criativo, uma vez que a criação seria essa própria união que empodera a criatura com o poder de criação.

Na pintura, o autorretrato precedeu a selfie em estados de habitar tempos e mundos: Salvador Dali imprimiu em sua figura o surrealismo de suas obras; Frida Kahlo mostrou sua saúde em declínio em várias etapas e Van Gogh registrou os estados emocionais desviantes até a automutilação da orelha. Rosário (2008), em seu texto denominado $O$ corpo eletrônico, afirma que a multiplicação de imagens põe em circulação novos "vocabulários imagéticos", que não são somente novos termos para tratar a técnica, mas ainda uma relação direta entre apropriações tecnológicas, comportamentos e criações. Assim sendo, o próprio conceito e a utilização de imagens se transformam, criando novas formas de significar. Ainda segundo a autora, a imagem funciona "[...] como socializadora de sentidos, de crenças, de valores, de ideias, de comportamentos. Afinal, através dela é possivel aos sujeitos interagir, construir, reconstruir sentidos e partilhá-los" (ROSÁRIO, 2008, p. 5). Ela acrescenta ainda:

Nessa via, começa-se a vislumbrar o quanto a imagem pode funcionar como socializadora de sentidos, de crenças, de valores, de ideias, de comportamentos, bem como produto estético.
Afinal, através dela é possivel aos sujeitos interagir, construir, reconstruir sentidos e partilhá-los e, ao mesmo tempo, desenvolver maneiras diferenciadas e inovadoras de representar, de pensar e de agir em sociedade. (ROSÁRIO, 2008, p. 5)

Por fim, entendemos que as imagens e, entre elas, as imagens de si e de mundos partiIham de um sensivel, de uma vontade política de estética, partilham de um comum, de uma vontade de habitar o presente. Ou seja, prosseguem umas nas outras engendrando novas composições/criações nos/com os currículos individuaiscoletivos e as redes educativas cotidianas que tecemos, em meio às quais somos tecidos, na medida em que elas apresentam novas questões para pensarmos os modos pelos quais se produzem as éticas, estéticas e políticas de existência e as narrativas sobre a vida e as práticas de ensinaraprender e de afetar e ser afetado dentrofora das escolas.

Os autores das selfies são, como diz Soares (2009, p. 151), apropriando-se de um conceito de França (2006), "sujeitos em comunicação", que seriam mais do que apenas enunciadores de discursos ou leitores de textos. Esses sujeitos em comunicação seriam sujeitos "enredados em teias de relações", porque as relações passam a constituir esses sujeitos: a relação com o outro, a relação com o simbólico e a relação consigo mesmo (SOARES, 2009).

Os sujeitos "em" comunicação não são os mesmos que os sujeitos "da" comunicação, alerta Soares (2009). De tanto ser ouvida, dita e reproduzida, a expressão sujeito da comunicação performa uma condição muito diferenciada dos sujeitos em comunicação, pois a primeira expressão indica que os sujeitos se limitam a reproduzir o comunicacional que está dado. Não haveria criação no termo sujeito da comunicação, mas apenas passividade e reprodução. Contudo, quando os sujeitos se colocam em comunicação, criam-se, coengendram-se, transformam-se em outros e são transforma- 
dos por outros, e a partir dos outros. Nessa perspectiva de "sujeitos em comunicação", enfatizamos ainda mais a importância da selfie nas escolas, pois compreender como se produzem os sujeitos, em meio a relações de poder que se imbricam intensamente com as relações de comunicação e com as capacidades que nos são exigidas, "[...] nos possibilita não só saber quem somos e como vivemos, mas, talvez, recusar o que somos e imaginar e construir o que queremos ser" (SOARES, 2009, p. 154).

França (2006) afirma que o sujeito em comunicação não seria um sujeito no singular, mas um sujeito no plural, com relações mediadas discursiva e imageticamente. Os sujeitos em comunicação encontram-se em relação de mútua afetação. Uma foto compõe com outra foto, ainda que ambas não tenham sido destinadas incialmente a isso. "A ação que constitui os sujeitos em comunicação, segundo França, é portanto, 'a ação de afetar e de ser afetado pelo outro através de materiais significantes'"(SOARES, 2009, p. 155). Esses sujeitos em comunicação, praticantes de selfies, imprimem diferentes sentidos sobre/na/com a escola e sobre/no/com o currículo.

O filósofo e historiador de arte Georges Didi-Huberman (2017) afirma que as imagens trazem questões específicas e interessantes para pensarmos nosso tempo e lugar. E o nos-

\section{Referências}

ALVES, Nilda. Imagens das escolas: sobre redes de conhecimentos e currículos escolares. Educar em Revista, Curitiba, Editora da UFPR, n. 17, p. 53-62, jan./jun. 2001. Disponível em: <http://www.scielo. br/pdf/er/n17/n17a05.pdf>. Acesso em: 20 abr. 2017.

ALVES, Nilda. A compreensão de políticas nas pesquisas com os cotidianos: para além dos processos de regulação. Educação \& Sociedade, Campinas, v. 31, n. 113, p. 1195-1212, out./dez. 2010. Disponivel em: <http://www.scielo.br/pdf/es/v31n113/08.pdf>. Acesso em: 10 mai. 2017. so trabalho seria, para Didi-Huberman (2017), olhar para as imagens ou criar imagens para descontruir clichês. No caso específico do que trata este trabalho, o clichê da indisciplina, o clichê da desordem, o clichê do desinteresse etc. Por isso, apostamos que as selfies se alimentam entre si e constroem o que Didi-Huberman (2017) chama de montagem. "O importante é colocar em relação as imagens porque elas não falam de forma isolada" (DIDI-HUBERMAN, 2017). As fotos, para o filósofo, são um legado da memória, têm um valor testemunhal. Seria um testemunho e também uma esperança, porém, não uma esperança para o fotógrafo, mas para o futuro, pois, de acordo com Didi-Huberman (2017), a imagem será sempre uma relação entre o desejo, uma vontade de ir para o futuro e a memória. "Uma imagem será sempre um gesto" (DIDI-HUBERMAN, 2017), e nós desejamos que os gestos de selfies proliferem nas escolas, compondo currículos nas/ com as redes educativas e tornando visivel tudo o que foi invisibilizado, porque toda análise de uma imagem e toda imagem têm uma dimensão política e essa dimensão política, segundo Didi-Huberman (2017), torna visivel a sobrevivência, os anacronismos, os encontros de temporalidades contraditórias que afetam cada objeto, cada acontecimento, cada pessoa e cada gesto.

BARTHES, Roland. A câmara clara: nota sobre a fotografia. Tradução de Júlio Castanõn. Rio de Janeiro: Nova Fronteira, 1984.

BERGSON, Henri. Matéria e memória. São Paulo: Martins Fontes, 2002.

BRUNO, Fernanda. Circuitos de vigilância: controle, libido e estética. In: LEAL, Bruno Souza; MENDONÇA, Carlos Camargos; GUIMARÃES, César. (Orgs.). Entre o sensivel e o comunicacional. Belo Horizonte: Autêntica, 2010. p. 253-273. 
CANCLINI, N. G. Fotografia e ideologia: seus pontos comuns. In: FUNARTE/INFOTO. Feito na América Latina - II Colóquio Latino-Americano de Fotografia (México, 1981). Rio de Janeiro/México, Ministério da Cultura/Conselho Mexicano de Fotografia, 1987.

CERTEAU, Michel de. A invenção do cotidiano: 1. Artes de fazer. Petrópolis, RJ: Vozes, 1994.

DELEUZE, Gilles. Diferença e repetição. Rio de Janeiro: Graal, 1988.

DIDI-HUBERMAN, Georges. A sobrevivência dos vagalumes. Belo Horizonte, MG: Editora UFMG, 2011.

DIDI-HUBERMAN, Georges. "As imagens não são apenas coisas para representar". Entrevista concedida a Verônica Engler. Disponivel em: <http:// www. sul-sur.com/2017/06>. Acesso em: 19 jun. 2017.

DUBOIS, Phillipe. $\mathbf{0}$ ato fotográfico e outros ensaios. São Paulo: Senac, 2010.

FRANCASTEL, Pierre. A realidade figurativa. São Paulo: Perspectiva, 1993.

FLUSSER, Vilém. A filosofia da caixa preta: ensaios para uma futura filosofia da fotografia. Rio de Janeiro: Relume-Dumará, 2002.

FRANÇA, Vera. Sujeito da comunicação, sujeitos em comunicação. In. GUIMARÃES, César; FRANÇA, Vera. (Orgs). Na mídia, na rua: narrativas do cotidiano. Belo Horizonte: Autêntica, 2006. p. 61-88.

GONÇALVES, Marco Antônio; HEAD, Scott. Devires imagéticos: a etnografia, o outro e suas imagens. Rio de Janeiro: 7Letras, 2009. p. 5-35.

GUIMARÃES, César. O que ainda podemos esperar da experiência estética. In: GUIMARÃES, César. (Org.). Comunicação e experiência estética. Belo Horizonte: UFMG, 2006. p. 13-26.

GUMBRECHT, Hans Ulrich. Produção de presença: 0 que o sentido não consegue transmitir. Tradução de Ana Isabel Soares. Rio de Janeiro: Contraponto; Ed. PUC-Rio, 2010.

JENKINS, Henry. Cultura da convergência. São Paulo: Aleph, 2009.
KOSSOY, Boris. Os tempos da fotografia: o efêmero e o perpétuo. Cotia, SP: Ateliê Editorial, 2007.

MARTINS, José de Souza. Sociologia da fotografia e da imagem. São Paulo: Contexto, 2008.

MINK, Janis. Duchamp. São Paulo: Taschen, 2000.

MISKOLCl, Richard. A gramática do armário: notas sobre segredos e mentiras em relações homoeróticas masculinas mediadas digitalmente. In: PELÚCIO, Larissa et al. (Orgs.). Olhares plurais para o cotidiano: gênero, sexualidade e mídia. Marília, SP: Oficina Universitária; São Paulo: Cultura Acadêmica, 2012. p. 32-52.

NICHOLS, Bill. La representacion de la realidad: cuestiones y conceptos sobre el documental. Barcelona: Paidós, 1997.

RANCIÈRE, Jacques. A partilha do sensivel: estética e política. São Paulo: Editora 34, 2009. p. 07-13.

REZENDE, Luiz Augusto. Microfísica do documentário: ensaio sobre criação e ontologia do documentário. Rio de Janeiro: Beco do Azougue, 2013.

RODRIGUES, Nelson; CASTRO, Ruy. Flor de obsessão: as 1000 melhores frases de Nelson Rodrigues. São Paulo: Companhia das Letras, 1992.

ROSÁRIO, Nísia Martins do. O corpo eletrônico. Intexto, Porto Alegre, UFRGS, v. 1, n. 18, p. 1-13, jan./ mai. 2008.

SOARES, Maria da Conceição Silva Soares. A comunicação praticada com o cotidiano da escola. Vitória: EspaçoLivros, 2009.

SONTAG, Susan. Sobre fotografia. São Paulo: Companhia das Letras, 2004.

VILLAÇA, Nízia. A edição do corpo: tecnociência, artes e moda. Barueri, SP: Estação das Letras, 2007.

WULF, Christoph. Homo pictor: imaginação, ritual e aprendizado mimético no mundo globalizado. Tradução de Vinicius Spricigo. São Paulo: Hedra, 2013.

Recebido em: 10.07.2017

Aprovado em: 30.10 .2017 
Maria da Conceição Silva Soares é Pós-Doutora em Educação UERJ/RJ. Professora do Programa de Pós-Graduação e Educação da Universidade do Estado do Rio de Janeiro (PROPED/Uerj). Coordenadora do Grupo de Pesquisa Currículos, Narrativas Audiovisuais e Diferença (CUNADI).e-mail: ceicavix@gmail.com

Rua São Francisco Xavier, 524 Grupo 12.037-F Maracanã, Rio de Janeiro.Celular (27) 999617848

Vanessa Maia Barbosa de Paiva é Doutora em Educação UFES/ES. Professora do Departamento de Letras, Artes e Cultura - Curso de Jornalismo - da Universidade Federal de São João del-Rei (MG). Membro do Grupo de Pesquisa Currículos, Narrativas Audiovisuais e Diferença (CUNADI). e-mail: vanesssamaia@gmail.com

Prédio ReUni II. Avenida Visconde do Rio Preto s/n, bairro Colônia do Bengo, São João del-Rei/MG. Celular (27) 999829535

João Barreto da Fonseca é Doutor em Comunicação e Cultura UFRJ/RJ. Professor do Departamento de Letras, Artes e Cultura - Curso de Jornalismo - da Universidade Federal de São João del-Rei (MG). Membro do Grupo de Pesquisa Currículos, Narrativas Audiovisuais e Diferença (CUNADI). e-mail: jombarreto@gmail.com

Prédio ReUni II. Avenida Visconde do Rio Preto s/n, bairro Colônia do Bengo, São João del-Rei/MG. Celular (27) 999384583 